\title{
A Discursive Psychological Analysis of Islamic Sermons on Homosexuality
}

\author{
Mohd Asyraf Zulkffli \\ Centre for Language Studies and Generic Development \\ Universiti Malaysia Kelantan, City Campus, Malaysia \\ E-mail: asyraf.z@umk.edu.my \\ Radzuwan Ab Rashid (Corresponding author) \\ Centre of English Language Studies, Faculty of Languages and Communication \\ Universiti Sultan Zainal Abidin, 21300 Kuala Nerus, Terengganu, Malaysia \\ E-mail: radzuwanrashid@unisza.edu.my
}

Received: 21-05-2016

Published: 01-11-2016
Accepted: 10-08-2016

doi:10.7575/aiac.ijalel.v.5n.6p.190
Advance Access Published: September 2016

URL: http://dx.doi.org/10.7575/aiac.ijalel.v.5n.6p.190

\begin{abstract}
This paper aims to provide insights into the delivery of Islamic sermons in regards to homosexuality. The spoken discourse which constitutes data for this study were generated from the sermons delivered by two Malaysian preachers. These sermons were retrieved from the video sharing website, Youtube. The two preachers were chosen because of their popularity and huge following. The spoken discourse was analyzed using the Discursive Psychology (DP) approach, more specifically, the Discursive Action Model (DAM) proposed by Edwards and Potter (1992). The analysis shows that these preachers expertly employed DP strategies in maneuvering their sermons so that Islamic ruling on the sinfulness of homosexuality is unflinchingly delivered. At the same time the rest of the Muslim communities are urged to treat LGBT individuals humanely. This paper thus challenges the notions that Islam is inherently homophobic and that Muslims who believe that homosexuality is a sin would necessarily discriminate against homosexuals.
\end{abstract}

Keywords: Discursive psychology, Homosexuality, Sermons, Malaysia, Preachers, Islam

\section{Introduction}

The Lesbian, Gay, Bisexual, and Transgender (LGBT) Movement has gained great momentum in our current day and age. Efforts to legitimize homosexuality are taken in such a strategic, sweeping manner so much so that the positive homosexuality representation in the Hollywood media has been at an all-time high (Watson \& Haider-Markel, 2014). The fight for sexual freedom is seen as a fight for universal human rights. When countries abort laws pertaining to homosexuality, such as the rights for same-sex marriage or law against sexual discrimination, it will be seen as victory against barbaric customs and outdated mentalities (Lekus, 2015).

Conversely, the promotion and glorification of homosexuality as a social construct and a marker of modernity and advancement of society, pose great problems to Islamic Ummah (community) worldwide. All four main schools of thoughts of Islam (Hambali, Hanafi, Syafii and Maliki) view Homosexuality as not only a sin but one of the gravest of sins (Mission Islam, n.d). Hence, in the face of growing global pressures to conform to the Western standard of Human Rights, Muslims face a difficult situation - either to conform to the idea of homosexuality as a form of independence and gain acceptance and respect of the global community or to resist such imposition and be viewed as backdated communities.

Against this backdrop of moral conundrum, Muslim communities and countries which hold Islamic stands in regards to LGBT issues face strong criticism for the way they treat LGBT individuals within their own community. Human Rights Watch Organization, for example, has criticized Indonesia on a number of LGBT rights related issues namely - banning of TV or radio programs deemed as normalizing homosexuality; Indonesian Psychiatric Association's classification of homosexuality as mental illness; and Islamic organization's stand on homosexuality whereby it is regarded as incompatible with human nature (Kine, 2016). Most Muslims would see criticism of these issues as unfair because Indonesia, as a Muslim-majority country ought to have the right to implement policies that are in line with Islam. However, not all criticism of the Muslim community in regard to homosexuality is completely unfounded. Reid (2016) highlights the breach of LGBT individuals' human rights in the form of routine harassment by religious police and enforcement of harsh punishment, such as public lashing, imprisonment, and death penalty in countries, such as Malaysia, Brunei, Egypt, Morocco, Nigeria, Gambia, and Aceh province in Indonesia. Such treatments of LGBT communities in the name of religion are tantamount to oppression.

On individual level, homosexual Muslims not only have to struggle against the social and religious stigma of being gay but also the law. In Malaysia for example, homosexual act is punishable with up to 20 years of jail time and whipping 
(see Malaysian Penal Code 1998, Section 377A and 377B). Further complicating this matter is their inner psyche. Broverman (2016) points out that LGBT individuals in United States are far more likely to suffer from mental illness than heterosexuals individuals. Homosexuals have to face great inner struggles. They have to reconcile their way of life with societal and religious pressure and thus, expose them to mental disorders, such as major depression, generalized anxiety disorder, suicidal tendency, and substance abuse (De Angelis, 2002).

In Malaysian context, the dialogue on homosexuality is still rife with prejudice and ignorance. In 2012, the Malaysian Education Ministry endorsed a checklist on how to spot gays and lesbians. Some of the items in the checklist to spot gays were "having a muscular body and like to show their body by wearing V-neck and sleeveless t-shirt" and "prefer tight and light-coloured clothes" whilst the checklist to spot lesbians included "besides their female companions, they will distance themselves from other women" and "Like to hang out, have meals and sleep in the company of women" (Mosbergen, 2012). The checklists made news item in international media, such as the Huffington Post and the Daily Mail UK (see Mosbergen, 2012; Thompson, 2013). Needless to say, Malaysian Education Ministry faced criticism and was ridiculed for its ignorance on the issue of homosexuality (Mosbergen, 2012; Thompson, 2013). The checklists were simplistic whereby gay men were reduced to caricatures of muscular men wearing a certain style of clothing instead of the actual diverse and complex identity that they actually have. The checklist for lesbian women on the other hand, were nonsensical to say the very least. How did distancing oneself from other women not contradictory with the other item which was "like to hang out, have meals and sleep in the company of women"? The items for lesbians were just all over the place and this further accentuated the ignorance of the Education Ministry in regards to homosexuality. Other cases where government bodies' reactions to homosexuality received widespread attention are - the arrest of transsexuals in Negeri Sembilan which prompted clash between the Federal court and Sharia' Court (Suparmaniam, 2015); Enforcement of effeminate students to join "corrective-sexuality camp" (BBC News, 2011); and most recently, claim by Deputy General of Police that openly gay people can't become cops (Palansamy, 2016). On top of all of this, the most infamous case regarding homosexuality in Malaysia has got to be the Anwar Ibrahim's sodomy trial. Though a lot of International Human Right bodies claim that the case was politically-charged, the details of same-sex sexual act were widely reported in the mainstream media. This surely affects the general Malaysians' psyche regarding homosexuality (Doherty, 2015).

Amidst various pressures surrounding the issue of homosexuality, Muslims are forced to take a stand. On one hand, there are the pro-LGBT groups which fight for legalization and promotion of LGBT movement and cultures. On the other hand, there are government bodies and Islamic organizations which take aggressive stands in combating the LGBT movements so much so that they disregards LGBT individuals' human right through law enforcement and promotion of violence against the group. The field of sexuality also suffers from lack of studies done from Islamic perspective. Hence, it is crucial for Muslim researchers to contribute to this field of study. Most studies that come from the Western world see LGBT as a movement that should be promoted and celebrated. The tone of such studies would not be beneficial for Muslims who view LGBT as sinful.

Thus, Muslims who strive to portray Islam as a progressive and peaceful religion without undermining Islamic ruling on homosexuality face a difficult situation. Often, Muslims would turn to Islamic preachers for guidance on how this global phenomenon ought to be approached. Hence, this paper aims to study how Islamic religious sermons are delivered in Malaysia. This study is important in shedding some light on how Islamic preachers translate the teaching of Islam to its audience; and to see the intricacy of language they use in addressing the subject of homosexuality.

\section{Literature Review}

\subsection{Homosexuality as a Social Construct}

Matters of sexuality have always been a subject of fixation throughout the progression of our society. Foucault (1978) claims that sexuality is a social construct. He relates this statement with the illustration of how power structure and resistance of the said power structure had influence on the way we talk about sexuality today. For example, the regulation of sexual relationship whereby only sexual relations between married people was lawful and conversely sexual intercourse done outside of marriage and sexual intercourse of homosexuals, the mentally ills, and criminals were made unlawful; was done for the sake of preserving health and maintaining procreation. Foucault further argues that the creation of the homosexual identity was only initiated in the $19^{\text {th }}$ century. Before that, the act of sodomy between people of the same sex was only seen as a feature of a person. During the Victorian Era, the act of sodomy had been classified as being only one of the aspects of being a homosexual. Thus, homosexuality has become an identity that affects our personality and behavior (Foucault, 1978).

The notion of homosexuality in the West also has gone through perspectival shift. In the time of Greek and Roman Empire, homosexuality was not perceived in a negative light. Surviving tales of love between men from these times are aplenty. In his text, Symposium (dated 380 BCE), Plato suggests an entire army to be made up of same-sex lovers. Love, he argues, would turn even the most cowardly of men into the bravest of hero. However, the arrival of Christianity in England and America drastically changed the way society at that time viewed homosexuality. The book of Leviticus states that "You shall not lie with a man as you do with a woman: that is an abomination" (Leviticus 18:22). Parts of Europe and America even imposed death penalty to those who engaged in homosexual acts (Watson \& Haider-Markel, 2014).

In the South East Asia context, sexual and gender deviants had enjoyed considerable rights and even special status in the past. The Bugis of South Sulawesi for example, acknowledged five gender categories. Aside from males and 
females who act out their appropriate gender roles according to their biological markers; Bugis also acknowledge males and females who act out opposite of their gender roles. Then, there is the bissu who holds a special status in the South Sulawesi Bugis mythology. Bissu has to embody both the female and male gender in their quest as priest of the community. Not only that, the bissu must also be able to connect with the spirit world whereby it is believed that their being can channel divinity in order for them to bless rituals or events of their community (Graham, 2002). In Malaysian context on the other hand, the status of effeminate, often cross-dressing, Mak Andam as wedding organizer has long been accepted and respected in the community. Even more shocking, was the existence of 'homosexual villages' in Kelantan up to the 1960s. These specialized villages were home to only males who were engaged in homoerotic acts. Most of them worked as entertainers of the traditional Mak Yong dance. It is interesting to note that they were not only accepted, but their status as performers were revered as well. Their villages were integrated into the communities - one village was even adjoined to the Sultan Palace. They earned relatively higher income and were under the patronage of the Kelantanese Royal (Peletz, 2009).

Like Christianity in the West, Islam also played a great role in the admonishment of homosexuality in the Arab and South East Asian Muslim communities. Muslim societies nowadays are considered to be the most resistant against LGBT ideology (Habib, 2010). However, looking at the earlier time of the Arab and South East Asian Muslim world where sexual and gender deviants were tolerated even until the 1960s, one may wonder - at what point did the Muslim communities start to take a hard stance against homosexuality? The link to this can be found in the origin of the Malaysian Penal Code against homosexuality which originated from the colonial era (Williams, 2010). Victorian Era in Britain saw rampant persecution and condemnation of homosexuals and with the advent of Colonialism, such value took root and started to affect the colonialized parts of the world. Ironically, homosexuality today is seen as a product of the West; resisting it is considered to be a Post-colonial struggle against Western Ideology that is trying to undermine the Islamic faith and identity.

In Malaysia however, a point in history whereby the discourse upon homosexuality became markedly more hostile may be that of the persecution of the former deputy Prime Minister of Malaysia, Anwar Ibrahim for sodomy in 1998. According to Williams (2010), former Prime Minister, Mahathir at that time used the sodomy trial not only as a mean to eliminate his political rival through prison sentencing, but also to tarnish his rival's reputation. It was thought that such accusation of vile, disgusting conduct which was sodomy would surely affect the people's trust towards Anwar Ibrahim. Following that, the government's tone regarding homosexuality had taken an increasingly hostile note. In September 2000, a top official of Malaysia's Islamic Affair Department denounced homosexuality by calling it a major sin - a fact which is not untrue. He however, furthered his denouncement of homosexuals by saying that homosexuality was worse than murder and that homosexuals were shameless people. In United Nations Assembly, Malaysian officials had played major roles in dissenting several resolutions which called for recognition of sexual minorities. Furthermore, Former Prime Minister Mahathir Mohamed had made several disparaging remarks towards Anwar Ibrahim regarding his homosexuality; one example was him saying that a Muslim-majority country like Malaysia should not have a gay prime minister (Williams, 2010). Noor (2009) also further expounded upon the sodomy trial. Noor criticized government bodies, opposition parties, as well as major NGOs for failing to state the obvious of this matter - the law regarding homosexuality was outdated, and ought to be abolished.

\subsection{Islam and Homosexuality}

The four main schools of Islamic thought unanimously rule the act of homosexuality to be one of the gravest of sins. The Quran and Sunnah of Prophet Muhammad which are the Muslims main tenets of faith have explicitly condemned homosexuality as an act of transgression against Fitrah (essence of men). The story of the People of Lut is detailed in the Quran as well as mentioned in the hadith as a cautionary tale against the act of homosexuality "For ye practice your lusts on men in preference to women : ye are indeed a people transgressing beyond bound" (Quran 7:81, Yusuf Ali Translation). In hadith narrated by Jabir ibn Abdullah : Allah's Messenger(peace be upon him) said, "The thing I fear most for my people is what Lot's people did." Transmitted by Tirmidhi and Ibn Majah - (Al- Tirmidhi : Hadith 3577).

It must be noted that Islam only rules the sexual acts of homosexuality to be sinful. Islam however empathizes with individuals who are struggling with their homosexual desire. Individuals with homosexual desire are commanded to pray, make du'a (supplication), give charity and never give up on the Mercy of Allah (Mission Islam, n.d). Contrary to the often misunderstood concept of Jihaad or 'struggle' by the westerners, the greatest Jihad in Islam is actually against evil ideas, desires and powers of lust, anger, and insatiable imagination (Ahlul Bayt Digital Islamic Library Project, n.d).

This notion of homosexuality as an act of transgression however has been challenged by minority of Muslims. This group does not accept homosexuality as sinful. They believe that the act that is condemned by Allah swt in the Quranic chapter about the People of Lut is actually that of same-sex sexual assault and rape. They also believe that the Quranic interpretation is skewed by earlier Islamic scholars who are of homophobic predisposition. Hence, this group calls for independent interpretation of the Quran and complete disregard of the Sunnah and the Scholars' rulings (Kugle, 2014). Though admittedly, individuals and groups who are fighting for legitimization of homosexuality have the best of intention and have done great in advancing the dialogue for the rights of homosexual Muslims, we couldn't agree with their view. The Quranic and Sunnah rulings against homosexuality are clear. The position of the earlier scholars of Islam is fair and the Islamic ruling against homosexuality is based on concrete, systematic, and sound reason. The field of Usul al Fiqh or Islamic Jurisprudence is also subjected to rigorous methodology (Hallaq, 1997). Hence, efforts to undermine rulings pertaining homosexuality by earlier scholars of Islam are baseless. 


\section{Methodology}

Three short videos (duration of $2-6$ minutes) featuring two prominent Islamic figures in Malaysia, Dr Asri Zainal Abidin and Ustaz Azhar Idrus, were chosen to be analyzed. These videos were taken from the video-sharing website, YouTube. These two figures were chosen due to their popularity and huge following in Malaysia. Since the sermons were delivered in Malay, the excerpts presented in this paper are the translated version. The spoken discourse were analyzed using the Discursive Psychology (DP) framework, more specifically, the Discursive Action Model (DAM) proposed by Edwards and Potter (1992).

Discursive Psychology was first proposed as general methodology or theory and critique for research in response to the perceived inadequacy in the study of social psychology. Social Psychology is concerned with interaction of individuals in relation to their society whereby the influence or perceived influence of society towards individuals' perceptions, attitudes, or behaviors are studied (Gilbert, Fiske \& Lindzey, 1998). Proponents of Discursive Psychology see some problems in the way social psychologists conduct their research. Social Psychology's emphasis on language as expression on the working of the minds poses problems when subjects produce inconsistent or varied accounts of events. These inconsistencies or variability are often treated as undesirable and thus, are prone to be ignored or manipulated. This is where Discursive Psychology is different. Discursive Psychology sees language features like inconsistencies and variability in term of the context in which the discourse is presented. In Discursive Psychology framework, features of speech are perceived to carry out functional purpose (Edwards, 2005). Thus, psychological themes like memory, attitude, and belief are susceptible to be manipulated through talk in order to achieve the speakers' rhetorical intention.

There are lots of different theory and methodology that can be applied in Discursive Psychology research. Edwards and Potter (1992) came out with Discursive Action Model (DAM) as guideline to achieve greater coherence in Discursive Psychology studies. The following are the summary of the content of DAM:

Discursive Action
Action
1. The focus in on action, not cognition.
2. Remembering and attributing become, operationally, reportings (and accounts, description, formulations, version
and so on) and the inferences that they make available.
3. Reportings are situated in activity sequences, such as those involving invitation refusals, blamings and defences.
Fact and interest
4. There is a dilemma of stake and interest, which is often managed by doing attribution via reports.
5. Reports are therefore constructed/displayed as factual by way of a variety of discursive techniques.
6. Reports are rhetorically organized to undermine alternatives.
Accountability
7. Reports attend to the agency and accountability in the reported events.
8. Reports attend to the accountability of the current speaker's action, including those done in the reporting.
9. The latter two concerns are often related, such that 7 is deployed for 8, and 8 is deployed for 7.
(Edwards and Potter, 1992, p.154)

As can be seen in the summary of DAM above, Edwards and Potter (1992) have established three major components that are crucial in Discursive Psychology analysis. They are Action, Fact and Interest, and Accountability. The concern on Action, as elaborated earlier, is what makes Discursive Psychology different from Social Psychology. Discursive Psychology studies communication, interaction, argument; and how these practices are organized in different contexts to perform actions. Psychological themes, such as memory and remembering are not merely perceived as cognitive elements of an individual but rather, are treated as actions that are performed through the giving of reports of an event. The contexts in which memory and remembering occur are also important. These discursive actions are organized in sequence to manipulate issues involving blame, responsibility, reward, compliment etcetera.

The Fact and Interest component of DAM, deals with motivations of the speakers. In Discursive Psychology, participants of talks are seen as investing in producing an account that is in line with their Stake and Interest. Thus, speakers have to be mindful of how they present their account so as to avoid it from being undermined by their perceived interest. Edwards and Potter (1992) further argues that participants of discourse ought to be deemed as subjected to the dilemma of stake or interest. The employment of reports and versions are often used in the management of this dilemma. To illustrate the mechanism of stake and interest, DAM was applied in a number of courtroom discourses where blame or innocence was established through variety of discourse strategies, such as group membership categories and role and trait talk. All in all, the Fact and Interest component of DAM seeks to examine how versions or accounts of speakers are constructed in a way that it would be thought of as being factual. Main techniques of establishing fact are presented below:

Category Entitlement - A member of certain group is expected to be well-versed in matter related to the said group. Thus, attributing suitable group membership to oneself helps to strengthen the truthfulness of one's accounts. 
Vivid Description - By describing events in rich contextual details, speaker creates a feel of re-experience to an event as well as demonstrates that they have good and trustworthy observation skills.

Narrative - Framing a report in a particular narrative sequence can aid in generating plausibility of an event as well as setting up context of deniability. Narrative sequence is often organized to attend to the causal, intentional and plausible connections of an event.

Systematic Vagueness - Vague reports of event is constructed to avoid them from being subjected to rebuttal. Vivid reports with rich detail are often vulnerable to being undermined. Global and vague formulation on the other hand, would prevent the speaker's account from being undermined while providing sufficient information to put a point across.

Empiricist Accounting - This is one of the main characteristics of scientific talk and writing. With this style, human actors are deleted by putting the sentences in passive form. The phenomenon is thus treated as an action that happens in its own right.

Rhetoric of Argument - This technique refers to the ways in which speakers or writers construct claims in logical, syllogistic or other well-known argument types. By constructing their claim in such a way, speakers create a sense of reassuring rationality and present the speakers as subjective in their actions.

Extreme Case Formulations - Extreme case formulation works by producing exaggerated scenario as base of comparison to justify and to make the speaker's report more effective.

Consensus and Corroboration - This technique helps with the strengthening of speakers' reports by framing the reports as something that witnesses would agree upon. Efforts are also made to ensure that the witnesses appear to be independent of the speakers' influence.

Lists and Contrasts - List, particularly three-part list, is useful in constructing descriptions which are deemed as complete or representative. Contrast on the other hand works by elaborately constructing alternative threatening accounts in an unconvincing and problematic manner (Edwards and Potter, 1992).

These nine components are the principles techniques related to the formulations of Facts and Interests. The last component of DAM is Accountability which does not only concern the subjects of the discourse but also includes the participants of the discourse. Edward and Potter (1992) point out that accountability of the current speakers should be made primary in data analysis. Current speakers would likely to have vested stake and interest when presenting their accounts. Thus, they will attend to their accounts in such a way as to deflect accountability. In analyzing accountability, the notion of 'Footing' plays a crucial part. Footing indicates the source in which the basis for speakers' account is taken. These bases could be from the speakers' direct experience and involvement, reports from reliable witnesses, or just passing information which the speakers just happen to get into (Edwards and Potter, 1992).

\section{Analysis and Discussion}

The three spoken discourses are analyzed according to the two main components of DAM, which are Action, Fact and Interest, and Accountability. To analyze the Action component of these sermons, the main action that was attempted to be performed by these preachers is established. From their sermons, it is clear that both preachers uphold the Islamic ruling that is followed by the majority of the Muslim communities worldwide - that Homosexual act is not only strictly forbidden but it is also one of the grievous sins in Islam. Dr Asri's tone was especially serious and assertive when he talked about Islamic prohibition for men who strive to resemble women, and women who strive to resemble men; and of actions by people who encourage homosexuals to embrace their homosexual tendency. In both instances, he raised his voice in a declarative manner, and stressed the word 'Haram' (Forbidden). In the Muslim context, the word 'haram' carries a serious effect. An action or thing which is 'haram' should be avoided at all cost; failure to adhere to the rulings will cause one to be in a state of sinfulness. Ustaz Azhar also asserted on the haram (forbidden) status of same sex relationship in one of his videos. With raised voice, he uttered that group of people who practise same sex relationship are "haram, kena laknat" which translates to not only as a forbidden practice but the ones practising it are also damned by Allah. When he uttered this part of his speech, Ustaz Azhar not only raised his voice, he also rushed his utterance, contributing to an effect of fluency, urgency and conviction to his sermon. From the examples provided, we can see that both of these preachers are unflinching in their proclamation of the unlawfulness of the homosexual practice in Islam. Thus, their strong denouncement of homosexual practice perform an action which works in urging Muslims to stay away from the homosexual practice and to see it as an admonishment to their faith.

Though only three sermons are studied in this video, we opine that they do reflect the majority way in which Islamic preachers address the issue of homosexuality. Hence, how do such sermons which are completely unforgiving in laying out the sinfulness of homosexual acts affect LGBT Muslims? Studies on homosexual Muslims by Zainon and Kamila (2011), and Jerome (2013) have shown clearly that most LGBT subjects in their studies accepted the contention that homosexuality is indeed sinful in Islam even though they themselves were involved in homosexual relationship or practice homosexual sexual act. Zainon and Kamila (2013) argue that LGBT individuals' understanding of Islamic teaching pose a great effect on their mentality and actions. Jerome (2013) also comes to the same conclusion in his study whereby he reviewed LGBT subjects of Dina Zaman's non-fiction, I Am Muslim. Jerome concludes that some Queer Malays are not able to express their queer identity due to their strong convictions of Islam.

The two preachers also utilize several strategies from Discursive Action Model (DAM) in presenting their sermons so as to protect their stake and interest in these discourses. One of those strategies was establishing their category (category entitlement) as someone who has the authority in the matter being addressed (Edwards and Potter, 1992). Islamic 
preachers are expected to be well-versed in the matter of religion and one of the markers of their expertise in Islam is their ability to cite the Holy Quran and Prophet Muhammad's hadith. Thus, by fluently citing these two holy books, these preachers managed to establish their category as people who are well-versed in the matter of religion. This can be seen when Ustaz Azhar further cemented his claim on the status of homosexuality by mentioning that all four Abrahamic holy books "Injil", "Taurat", "Zabur" and "Quran" as well as the Hadith of the Prophet had decreed that homosexuality is indeed not only a forbidden act but a damned act as well. Dr Asri and Ustaz Azhar also cited the Hadith in Arabic whereby Dr Asri expounded upon the hadith which prohibits men from resembling women and women from resembling men; while Ustaz Azhar expounded upon the hadith which talks about the manners for Muslims in forbidding evils. Other than establishing himself in the category of someone who has the authority to talk about Islam, Dr Asri also managed to associate himself as someone who has the authority to talk about gender and sexuality. In his sermon, he mentioned scientific work in the field of gender whereby some scholars argue whether a person's gender should be determined not just by looking at their reproductive organ but also their hormone, inner structure in the body etcetera. Thus, by establishing himself as an expert in matters of religion and science, Dr Asri managed to secure a point of legitimacy in delivering his sermon.

Other than that, Ustaz Azhar also employed several other components from DAM which are rhetorical device and vivid description (Edwards and Potter, 1992) in getting his point across. This is similar to the participants in Rashid, Rahman and Rahman's (2016) studies who also used rhetorical device and vivid description to engage their audience. In one part of his video, Ustaz Azhar used metaphor, which is one of the most popular rhetorical devices, to equate the people who practise lesbianism to be stupider than cow. In later part of the video he further elaborated his statements by stating that 'memang natang lembu bodo'- translation - 'indeed the animal, cow, is stupid'. Here, Ustaz Azhar went further by using the word 'natang' which is the colloquial Terengganu dialect of the word 'animal' and carries harsh connotation. The usage of metaphor by Ustaz Azhar was also further enhanced by the usage of vivid description:

-Lembu ade dok mmaing tine nge tine? Ade ok? Tak dok! Padahal lembu tu dok pass SPM.

Translation - [among] cows, are there any female cows that have sex with other female cows? Are there any? There're none! Though cows don't pass SPM (Malaysian Examination Certificate)

-Tengok kambing kang dok berok bbira jalang pepepepepepepe berok tapi tak dok, jatang dengang hok jatang tak dok...

Translation - look at the goats, shitting pepeppepepepe (onomatopoeia for shitting goat) by the side of the road but there are none of the males that have sex with other males...

The usage of vivid description by Ustaz Azhar works by supporting his rhetoric to make the acts of LGBT practitioners seem more idiotic whereby even the behavior of animals (cows and goats) could not outmatch their perverse sexuality. Hence, the usage of metaphor which is further enhanced by vivid description to describe the intellect of LGBT practitioner; and the colloquially harsh word 'natang' brought about a strong denouncement of the LGBT practice. As pointed out by Rashid (2016), rhetoric is a powerful device in persuading audience to take up the speaker's stance.

Though it seems harsh, this comparison is not unjustified if we look at the context in which it was uttered whereby this sermon actually addressed not only people who practise the LGBT lifestyle but also seek to legalize and promote this lifestyle to the Malaysian public. We can see a stark contrast in the way Ustaz Azhar addressed LGBT people in his another sermon whereby Ustaz Azhar stated that LGBT people are worse than "magnets" (referring to magnetic poles' repelling of the same pole). Here, we can see that Ustaz Azhar employed a softer metaphor in addressing homosexuality. Clearly, likening LGBT people to magnets is not as severe as likening them to cows. This is because, in this second video, Ustaz Azhar was not addressing the LGBT rights movements but rather a way to guide LGBT individuals. The rest of his sermon was also devoid of harsh tone and severe language where in the last part of his sermon, Ustaz Azhar emphasized on the value of brotherhood in combating homosexuality. In this part, another component of DAM which is narrative was employed by the preacher. He prescribed a narrative-like sequence in his advice - "jangan putus asa, teruskan nasihat kawan kita... tok jadi cara ni, cara ni. Jangang tinggal die" - translation "Don't give up, keep on giving advice to our friends... if this way doesn't work, use this way. Don't leave him" and; "Baca Bismillah mmolek, bersemayang hajat, berdoa lepah semayang, berkat kecekalang seorang sahabat nok tengok sahabat die beruboh, Allah buleh uboh bile-bile masa" - translation - "Read proper Bismillah (in the Name of Allah), perform hajat prayer (special prayer to ask for wish to be granted), recite du'a after solat, with the blessing of a friend's fortitude to see his friend changes [to stay away from homosexuality], Allah can change [the homosexual] anytime". By framing this advice in such narrative-like sequence, Ustaz Azhar attempted to make the audience feel like they are in the shoes of a friend who is trying to bring their LGBT friends to the true Islamic path. The employment of narrative by Ustaz Azhar also helps challenges the notion that Islam is inherently homophobic and that those who are opposed to homosexuality will resort to harsh treatment towards the homosexuals.

Thus, we can sum up that these sermons by Ustaz Azhar are varied in tone depending on the subject of his sermon. In regards to LGBT movement's efforts to legalize and normalize homosexuality, we can see how the use of especially harsh language and tone to address them affect the movement nowadays. Shah (2013) agrees to the notion that the sexual diversity movement's efforts to influence the legal, political, and religious aspects of Malaysian state have been largely ineffective. However, Shah also points out that the promotion of LGBT ideology has been bolder in the literary, arts, and entertainment scene. On the subject of humane treatment of homosexuals on the other hand, a different situation can be observed. In the study of stigma among homosexual men in Penang, Felix (2014) reveals that both 
Muslims and non-Muslims homosexual subjects of his study experienced negative treatments because of their sexuality. Such treatments included being verbally and physically abused, and alienated from their peers or community. These conducts by the communities also proved ineffective in 'curing' the homosexuals as the findings of the study suggest that stigma and discrimination from society only caused the homosexual individuals having their resolve and conviction in living up to their sexual identity strengthen (Felix 2014). Nevertheless, Shah (2013) highlights positive treatment of transsexual community by Federal Territories Islamic Affairs Department whereby religious instructions on matters related to HIV/AIDS are delivered to this community in a non-judgmental manner.

We can also see the use of 'three-part list' and 'extreme case formulation' (Edwards \& Potter, 1992) by Ustaz Azhar in one of his videos. Ustaz Azhar addressed the issue of efforts by certain parties to legitimize LGBT:

\section{Buleh nok suruh halalkan gay? nok suruh halalkan liwat? nok suruh halalkan lesbian - hubungan sejenis} sesama perempuan? nye paka gesek same die. Takdok aroh, bodo pade lembu.

Translation:

[How could they ask] to make gay halal(lawful)? To make sodomy halal? To make lesbian - same sex relationship between women halal? [vaginal] grinding with each other (chuckle). [They've] lost their way, [they're] stupider than cow.

There are several devices employed in strengthening the stake and interest of the speaker in the phrase above. The first one is the 'three-part list' (Edwards and Potter, 1992) whereby the phrase "nok suruh halalkan" or "to make lawful" were used in the beginning of the first three clauses. This works as an instrument of emphasize in which the phrase highlighted the great and all-encompassing efforts of the parties involved in the LGBT legitimization movement. The choice of word 'halal' is also an interesting case of extreme case formulation. Halal which is the opposite of haram or forbidden was used to describe sinful practice which is gay, sodomy and lesbian. The general Islamic community would unlikely consider these practices to be permissible anytime soon. The purpose of associating the word halal with something that is the opposite of it may work in a way of stressing the perversion of the LGBT movement activists. Other than that, Ustaz Azhar also used a fairly crass phrasing "nye paka gesek" (Malay for "grinding [with each other]") which describes the act of lesbian sexual act. The phrasing was followed with a slight chuckle which can be interpreted as ridiculing such act.

Finally, this paper will analyze the last main component of DAM which is Accountability (Edwards and Potter, 1992). In addressing homosexuality, Ustaz Azhar did not hold back in assigning accountability to the audience of his sermon. Ustaz Azhar's sermon took place in a mosque thus the audience of this sermon is perceived to be from among the more pious members of that Muslim community. He criticized that pious audience for not being mindful of the current development of the country in regards to homosexuality in which he claimed that the legalization of homosexuality is subjected to be approved in any time now. He further stated that the audience only cared about "making nasik" and "Mentekedarah" (Malay for "eating rice" and "eating greedily"); and on their own acts of worship. He claimed that his audience had abandoned their role in fixing the society. The phrase 'Nye berase ssohor ngat doh tu' -translation '([you] must've felt so vain)' also further accentuated his disdain for the group of people who are negligent of the society's wellbeing. Finally, he invoked the Lord's name by saying that Allah has caused all of these vices to happen because He wants the Muslims to play their roles and take actions against those vices. Thus, from these extensive examples, we can clearly see how Ustaz Azhar assigned accountability to his audience. Edwards and Potter (1992) however propose that accountability should be primarily analyzed in the context of the speaker's own discourse and see whether the speaker tries to deflect accountability or not. In this matter, we would contend that Ustaz Azhar was not trying to deflect accountability. This is apparent if we look at the footing that he used throughout this part of the sermon which is 'kite' (Malay for 'we'). Hence, when he listed all of those shortcomings among the pious Muslims, it is inevitable that he was also referring to himself. Not deflecting his own accountability lends Ustaz Azhar's discourse a touch of impassionate plea in addressing homosexuality.

\section{Conclusion}

This paper challenges the notion that Islam is inherently homophobic and that the religion encourages violence and discrimination to LGBT individuals. Both preachers employed a gentle and emphatic tone and language towards LGBT individuals who they deem as struggling against their evil desire. Only when they talk about Islamic rulings on homosexuality would they use strong and definitive language and tone. Ustaz Azhar's language is also especially harsh when addressing efforts made by LGBT movement groups to promote and legalize homosexuality in Malaysia. Between denouncing homosexuality and empathizing with the plight of the homosexual Muslims, we can see how these two preachers expertly use Discursive Psychology mechanisms, such as category entitlement, three-part list, and extreme case formulation as well as their way of constructing their religious discourse to perform action of prohibiting Muslims from practicing homosexuality.

All in all, efforts should be made in promoting this version of Islam to the government and Islamic bodies as well as general public so that Muslims would take a more tolerant and accepting attitude towards homosexuals in their community. For future research, analysis of more sermons in regards to homosexuality ought to be carried out to present a more comprehensive outlook of Islamic attitudes towards LGBT individuals. Analysis of preachers from outside of Malaysia as well as preachers who legalize homosexuality could also be an interesting topic of studies. 


\section{References}

Ahmad Azhari Abdul Aziz. (2014, November 27) Ustaz Azhar Idrus - BODO pada natang lembu[lesen gay].

[Video File] Retrieved from https://www.youtube.com/watch?v=NVRBTce1

fg\&index $=51 \&$ list $=$ LLwcOnVmK3 $x y A h W 7 \mathrm{cNmCtpBA}$

Ajeem Jims. (2016, 10 May) Dr Asri rakan sebilik gay, apa patut saya buat?. [VideoFile].

Retrieved from

https://www.youtube.com/watch?v=Gmw0MLGHVFM\&index=53\&list=LLwcOnVmK3xyAhW7cNmCtpBA

Broverman, N. (2016, March 18). How our intolerant society contributes to LGBT mental disorders. Retrieved from http://www.advocate.com/health/2016/3/18/how-our-intolerant-society-contributes-lgbt-mental-disorders

DeAngelis, T. (2002, February). New data on lesbian, gay and bisexual mental health.

Retrieved from http://www.apa.org/monitor/feb02/newdata.aspx

Doherty, B. (2015, February 10). Anwar Ibrahim guilty in sodomy case. Retrieved from https://www.theguardian.com/world/2015/feb/10/anwar-ibrahim-guilty-in-sodomy-case

Edwards, D., \& Potter, J. (1992). Discursive psychology. London: Sage.

Felix, M.S. (2014). Stigma as part of identity development of gay men in Penang - A qualitative study. Pertanika J. Soc. Sci. \& Hum. 22(3), $365-377$.

Foucault, M. (1978). The history of sexuality. New York: Pantheon Books.

Gilbert, D. T., Fiske, S. T., \& Lindzey, G. (1998). The handbook of social psychology. Boston:

McGraw-Hill.

Graham, Sharyn. (2002, June 14). Sex, gender, and priest in South Sulawesi, Indonesia. International Institute of Asian Studies Newsletter - Asian Homosexualities. Amsterdam.

Habib, S. (2010). Homosexuality in the Muslim world. In S. Habib (Ed), Islam and Homosexuality (pp. 37-50). Santa Barbara: Praeger.

Hallaq, W. B. (1997). A history of Islamic legal theories: An introduction to Sunnī ușūl al-fiqh. Cambridge: Cambridge University Press.

HambaFaqir Channel. (2013, January 4) (Soalan Dari UK) Kawan LGBT..Macamana Nak Nasihat?

- Ustaz Azhar Idris. [Video File] Retrieved from

https://www.youtube.com/watch? $==c$ XRREilryo\&index $=52 \&$ list=LLwcOnVmK3xyAhW7cNmCtpBA

Islam and Homosexuality. (n.d.). Retrieved August 09, 2016, from

http://www.missionislam.com/knowledge/homosexuality.htm

Jerome, C. (2013). The complexity of Malay muslim identity in Dina Zaman's I am Muslim. Gema Online Journal of Language Studies, 13(2),169-179.

Kine, P. (2016, March 16). What's behind the Indonesian president's troubling silence on LGBT persecution?

Retrieved from https://www.hrw.org/news/2016/03/16/whats-behind-indonesian-presidents-troubling-silence-lgbtpersecution

Kugle, S. A. (2013). Living out Islam: Voices of gay, lesbian, and transgender Muslims.

Lekus, I. (2015, June 26). VICTORY! Supreme court recognizes marriage equality. Retrieved from http://blog.amnestyusa.org/us/victory-marriage-equality-is-a-right/

Malaysia's anti-gay camp violates law says minister. (2011, April 20). Retrieved from http://www.bbc.com/news/world-asia-pacific-13141466 Malaysian Penal Code 1998, ss. 377A-377B.

Mosbergen, D. (2012, September 13). Guidelines for gay and lesbian symptoms endorsed by Malaysia education ministry spark outrage. Retrieved from http://www.huffingtonpost.com/2012/09/13/guidelines-for-gay-andlesbian-symptoms-malaysia-education-ministry_n_1881863.html

Noor, F. (2009, July 3). Who's afraid of sodomy? | The Nut Graph. Retrieved from http://www.thenutgraph.com/whos-afraid-of-sodomy/

Palansamy, Y. (2016, April 23). Deputy IGP: Openly LGBT people can't become cops even if qualified. Retrieved from http://www.themalaymailonline.com/malaysia/article/deputy-igp-openly-lgbt-people-cant-become-copseven-if-qualified

Peletz, M. G. (2009). Gender pluralism: Southeast Asia since early modern times. New York: Routledge.

Rashid, R.A. (2016). Topic continuation strategies employed by teachers in managing supportive conversations on Facebook Timeline. Discourse Studies, 18(2), 188-203.

Rashid, R.A., Rahman, M. F. A., \& Rahman, S. B. A. (2016). Teachers'engagement in social support process on a networking site. Journal of Nusantara Studies, 1(1), 34-45. 
Reid, G. (2016, January 07). Equality to brutality: Global trends in LGBT rights. Retrieved from

https://www.hrw.org/news/2016/01/07/equality-brutality-global-trends-lgbt-rights

Shah, S. (2013). The Malaysian dilemma: negotiating sexual diversity in a Muslim-majority

Commonwealth state. In: Human rights, sexual orientation and gender identity in the commonwealth: struggles for discriminalisation and change (pp. 261-286). Institute of Commonwealth Studies, School of Advanced Study, University of London.

Sharlet, J. (2010). Public display of affection: Male homoerotic desire and sociability in medieval Arabic literature. In S. Habib (E.d), Islam and Homosexuality (pp. 37-50). Santa Barbara: Praeger.

Thompson, P. (2013, January 15). If your son likes wearing v-neck jumpers it's a sign he's gay: Bizarre advice given to parents by Malaysian government. Retrieved from http:/www.dailymail.co.uk/news/article-2262842/Ifson-likes-wearing-v-neck-jumpers-sign-hes-gay-Bizarre-advice-given-parents-Malaysian-government.html

Watson, S., \& Haider-Markel, D. P. (2014). Gay rights movement. Social Science Journal, 50(4), 603-15.

Williams, W. L. (2010). Islam and the politics of homophobia: The persecutions of homosexuals in Islamic Malaysia compared to secular China. In S. Habib (E.d), Islam and Homosexuality (pp. 37-50). Santa Barbara : Praeger.

Zainon, S. \& Kamila, G. (2011). A discursive construction of homosexual males in a

Muslim-dominant community. Journal of Cross-Cultural and Interlanguage Communication, 30(3-4), 279-304. 